\title{
Pengaruh Metode Bercerita terhadap Kecerdasan Linguistik Anak Usia Dini di TK Se-Kecamatan Parakan, Temanggung Jawa Tengah
}

\author{
Faridl Musyadad ${ }^{1}$ Santi Ambar Ingrum² \\ Dosen Prodi PGSD IKIP PGRI Wates Yogyakarta1 ${ }^{1}$ Guru TK Negeri Pembina Parakan² \\ adad dong@yahoo.co.id ${ }^{1}$ s.a.ingrum@gmail.com ${ }^{2}$
}

Tujuan penelitian ini adalah 1) Untuk mengetahui tingkat keberhasilan penggunaan metode bercerita di TK se-Kecamatan Parakan, 2) untuk mengetahui tingkat kecerdasan linguistik anak usia dini di TK se-Kecamatan Parakan, 3) untuk mengetahui penerapan metode bercerita dalam meningkatkan kecerdasan linguistik anak usia dini di TK se-Kecamatan Parakan. Penelitian ini menggunakan jenis penelitian kuantitatif dengan rancangan Ex Post Facto. Subyek yang diteliti dalam penelitian ini adalah guru di TK se- Kecamatan Parakan. Metode pengumpulan datanya menggunakan angket, dan dokumentasi. Teknik sampling yang digunakan adalah simple random sampling. Populasi dalam penelitian ini ada 118 guru namun peneliti hanya meneliti sampel sejumlah 88 guru berdasarkan tabel Isaac dan Michael dengan taraf signifikan 5\%. Teknik analisis data dalam penelitian ini menggunakan analisis deskriptif, korelasi product moment, dan regresi linier. Hasil penelitian menunjukkan: hasil uji validitas dan reliabilitas N: 88 validitas $100 \%$, variabel $\mathrm{X}$ valid statistik $86,2 \%$ dan variabel Y reliabel $87,5 \%$. Hasil korelasi product moment diperoleh $r_{\text {hitung }}$ sebesar 0,475. Koefisien determinasi sebesar 22,5\%. Hasil uji regresi dalam grafik histrogram dan P-P Plot menyatakan bahwa data berdistribusi normal. Maka dapat disimpulkan ada pengaruh yang signifikan antara metode bercerita terhadap kecerdasan linguistik anak usia dini di TK se-Kecamatan Parakan sebesar 22,5\% dan 77,5\% dari faktor lain. Tingkat penggunaan metode bercerita di TK se-Kecamatan Parakan yaitu sering, sedangkan tingkat kecerdasan linguistik anak usia dini di TK se-Kecamatan Parakan yaitu baik.

Kata Kunci: bercerita, kecerdasan, linguistik

The purpose of this research is 1) To know the success rate of using storytelling method in kindergarten in Parakan sub-district 2) to know the level of linguistic intelligence of early child in kindergarten in Parakan sub-district 3) to know the application of story telling method in improving linguistic intelligence of child age early in kindergarten in Parakan sub-district. This research uses quantitative research type with Ex Post Facto design. Subjects studied in this study were teachers in kindergarten Parakan sub-district. Methods of data collection using questionnaires, and documentation. The sampling technique used is simple random sampling. The population in this study there are 118 teachers but researchers only examine a sample of 88 teachers based on tables Isaac and Michael with a significant level of 5\%. Data analysis techniques in this study using descriptive analysis, product moment correlation, and linear regression.

The results showed: the results of validity and reliability tests $N: 88100 \%$ validity, variable $X$ valid statistics $86.2 \%$ and $Y$ reliable $87.5 \%$. The result of product moment correlation is obtained $r$ count equal to 0,475. The coefficient of determination is $22.5 \%$. Regression test results in histrogram and P-P plot graphs indicate that the data is normally distributed. So it can be concluded there is a significant influence between the method of telling the linguistic intelligence of early childhood in kindergarten Parakan District as much as 22.5\% and $77.5 \%$ of other factors. Level of use of storytelling method in kindergarten Parakan District that is often, while the level of linguistic intelligence of early childhood in kindergarten of Parakan sub-district is good.

Keywords: telling stories, intelligence, linguistics 


\section{PENDAHULUAN}

Kondisi akhir-akhir ini begitu memprihatinkan. Banyak dijumpai kekerasan, tawuran/perkelahian antar berbagai pihak. Berbagai elemen dari pelajar hingga para pejabat saling tawuran, adu mulut dan sebagainya. Mereka hanya mementingkan ego masing-masing tanpa berpikir terlebih dahulu mana yang terbaik. Krisis moral seperti ini seharusnya tidak terjadi bila calon-calon pemimpin dibekali dengan pendidikan budaya dan karakter bangsa sejak dini. Karakter suatu bangsa akan semakin terpupuk bila warganya benar-benar menjunjung tinggi nilai-nilai kebudayaan yang sudah ada dan mengetahui asalusul sejarah bangsa itu sendiri. Sejarah bangsa seharusnya dikenalkan kepada anak sejak dini. Pengenalan sejarah bangsa yang tepat kepada anak usia dini adalah melalui metode bercerita Cerita sejarah yang menarik menyebabkan timbul rasa cinta dalam diri anak kepada bangsanya. Bagaimana cerita sejarah itu dikemas agar tidak membosankan dan anak-anak tertarik itulah tugas guru sebagai fasilitator.

Metode merupakan bagian dari strategi kegiatan. Metode dipilih berdasarkan strategi kegiatan yang sudah dipilih dan ditetapkan. Metode merupakan cara yang bersistem untuk memudahkan pelaksanaan suatu kegiatan guna mencapai tujuan yang telah ditentukan. Dr. Ahmad Tafsir memberikan pengertian metode adalah, "Cara yang paling tepat dan cepat dalam melakukan sesuatu". Sedangkan menurut Sukanto, "Cerita adalah suatu kegiatan yang dilakukan oleh guru kepada murid-muridnya, ayah kepada anak-anaknya, guru bercerita kepada pendengarnya. Suatu kegiatan yang bersifat seni karena erat kaitannya dengan keindahan dan bersandarkan kepada kekuatan kata-kata yang dipergunakan untuk mencapai tujuan cerita". Bercerita merupakan cara untuk meneruskan warisan budaya dari satu generasi ke generasi berikutnya (Gordon \& Browne, 1985: 324). Bercerita juga dapat menjadi media untuk menyampaikan nilai-nilai yang berlaku di masyarakat menurut Moeslichatoen R.

Metode bercerita merupakan salah satu metode yang banyak digunakan di Taman Kanak-kanak dengan membawakan cerita kepada anak secara lisan. Cerita yang dibawakan guru harus menarik dan mengundang perhatian anak serta tidak lepas dari tujuan pendidikan bagi anak Taman Kanak-kanak. Bila isi cerita dikaitkan dengan dunia kehidupan anak di Taman Kanak kanak, maka mereka dapat memahami isi cerita itu, mereka akan mendengarkannya dengan penuh perhatian, dan dengan mudah dapat menangkap isi cerita.

Menurut Moeslichatoen R, bahwa tujuan bercerita adalah, "Suatu cara yang ditempuh guru untuk memberi pengalaman belajar agar anak memperoleh penguasaan isi cerita yang disampaikan lebih baik. Melalui metode bercerita maka anak akan menyerap pesan-pesan yang dituturkan melalui kegiatan bercerita. Penuturan cerita yang sarat informasi atau nilai-nilai dapat dihayati anak dan diterapkan dalam kehidupan sehari-hari". Bercerita bukan hanya berfungsi sebagai hiburan tetapi juga merupakan suatu cara yang dapat digunakan dalam mencapai sasaran-sasaran atau target pendidikan. Metode bercerita dapat menjadikan suasana belajar menyenangkan dan menggembirakan dengan penuh dorongan dan motivasi sehingga indikator pembelajaran dapat tercapai.

\section{KAJIAN TEORI}

\section{Kecerdasan Linguistik}

Menurut Sumadi dalam bukunya Kecerdasan Anak, "bahwa kecerdasan linguistik adalah kecerdasan dalam mengolah kata, atau kemampuan menggunakan kata secara efektif baik secara lisan maupun tertulis" (2013: 287). Orang-orang yang cerdas dalam bidang ini dapat berargumentasi, meyakinkan orang, menghibur atau mengajar dengan efektif lewat kata-kata yang diucapkannya. Kecerdasan ini memiliki empat keterampilan yaitu: menyimak, mendengar, menulis dan membaca.

Secara efektif anak yang cerdas dalam bidang linguistik memiliki minat terhadap buku yang cukup tinggi. Mereka suka membuka lembar buku, bahkan sebelum mereka belum mampu membacanya. Cara belajar terbaik bagi anak-anak yang cerdas dalam bidang linguistik adalah dengan mengucapkan, 
mendengarkan, melihat tulisan dan membaca. Cara terbaik memotivasi mereka adalah dengan mengajak mereka berbicara, menyediakan banyak buku, rekaman, serta menciptakan peluang bagi mereka untuk mengekspresikan dirinya melalui tulisan.

Kaitannya dengan sistem neurologis, kecerdasan ini terletak pada lobus temporal yang berkaitan dengan memori, emosi, pendengaran dan bahasa atau disebut juga dengan istilah area pengendali ucapan (motor speech area).

Kecerdasan linguistik penting bukan hanya untuk keterampilan berkomunikasi melainkan juga penting untk mengungkapkan pikiran, keinginan dan pendapat seseorang. Anak-anak yang cerdas dalam linguistik memiliki kemampuan untuk menghargai kata-kata dan juga makna dari kata-kata tersebut baik yang tertulis ataupun yang terucap. Mereka mengembangkan kepekaan bahasa yang tajam dan dengan mudah dapat memanipulasi struktur dan sintaksisnya, fonologi atau bunyi dalam bahasa, semantik atau pemaknaan bahasa dan dimensi pragmatik atau penggunaan secara praktis bahasa untuk menyesuaikan dengan kebutuhan dan yang paling tepat adalah mereka dapat menggunakan bahasa untuk tujuan komunikasi yang mereka inginkan. Diantara penggunaannya termasuk retorik (mempengaruhi orang lain untuk bertindak), menemonik (mengggunakan bahasa untuk mengingat informasi), menjelaskan (menggunakan bahasa untuk menjelaskan) dan metabahasa (menggunakan bahasa untuk membahasnya sendiri).

\section{Metode Bercerita}

Ahmad Tafsir memberikan pengertian metode adalah "Cara yang paling tepat dan cepat dalam melakukan sesuatu". Sedangkan menurut Sukanto "Cerita adalah suatu kegiatan yang dilakukan oleh guru kepada murid-muridnya, ayah kepada anak-anaknya, guru bercerita kepada pendengarnya. Suatu kegiatan yang bersifat seni karena erat kaitannya dengan keindahan dan bersandarkan kepada kekuatan kata-kata yang dipergunakan untuk mencapai tujuan cerita"(2010: 45). Bercerita merupakan cara untuk meneruskan warisan budaya dari satu generasi ke generasi berikutnya (Gordon \& Browne, 1985:324). Bercerita juga dapat menjadi media untuk menyampaikan nilai-nilai yang berlaku di masyarakat menurut Moeslichatuoen R.

Metode bercerita merupakan salah satu metode yang banyak digunakan di Taman Kanak-kanak dengan membawakan cerita kepada anak secara lisan. Cerita yang dibawakan guru harus menarik dan mengundang perhatian anak serta tidak lepas dari tujuan pendidikan bagi anak Taman Kanak-kanak. Kehidupan anak-anak sangat berkaitan dengan lingkungan keluarga, sekolah dan luar sekolah. Kegiatan bercerita harus diusahakan menjadi pengalaman bagi anak di Taman Kanak-kanak yang bersifat unik dan menarik yang menggetarkan perasaan anak dan memotivasi anak untuk mengikuti cerita sampai tuntas. Dapat disimpulkan bahwa yang dimaksud dengan metode bercerita menuturkan atau menyampaikan cerita secara lisan kepada anak didik sehingga dengan cerita tersebut dapat disampaikan pesan-pesan yang baik. Dengan adanya proses belajar mengajar, maka metode bercerita merupakan suatu cara yang dilakukan oleh guru untuk menyampaikan pesan atau materi pelajaran yang disesuaikan dengan kondisi anak didik.

Anak-anak akan belajar menulis dengan cara semakin rumit dan cocok untuk menyampaikan gagasan mereka, meminta barang, mendokumentasikan kegiatan-kegiatan mereka dan memberi kesenangan dan kegembiraan. Ketika pengetahuan tentang tulisan meningkat, huruf-huruf dibentuk dan koleksi hurufhuruf tak bermakna semakin mendekati ucapan-ucapan fonetik. Akhirnya, mereka belajar bahwa ada bermacam-macam maksud menulis dan bahwa gaya menulis berubah sesuai dengan maksud itu.

Anak yang sering mendengarkan cerita akan mempunyai kosaka yang banyak serta kemampuan berbicara maupun berbahasanya akan meningkat. dari hal tersebut, apabila penggunaan metode bercerita secara sering dan terus menerus maka akan menyebabkan kecerdasan linguistik anak 
meningkat. namun sebaliknya, bila penggunaan metode bercerita jarang ataupun tidak sesuai dengan tekniknya maka akan menghambat kecerdasan linguistik anak.

\section{METODE}

Pendekatan penelitian ini menggunakan penelitian kuantitatif (positivistik) yaitu berlandaskan pada filsafat positivisme, digunakan untuk meneliti pada populasi atau sampel tertentu, pengumpulan data menggunakan instrumen penelitian, analisis data bersifat statistik, dengan tujuan untuk menguji hipotesis yang telah ditetapkan. (Sugiyono, 2009).

Jenis pendekatan ini adalah penelitian kuantitatif dengan rancangan Ex Post Facto. Penelitian Ex Post Facto merupakan pencarian empiris yang sistematis dimana peneliti tidak dapat mengontrol langsung data penelitiannya karena peristiwa telah terjadi atau karena menurut sifatnya dapat dimanipulasi.

Penentuan jumlah sampel berdasarkan tabel penentuan jumlah sampel dari populasi tertentu yang dikembangkan dari Isaac dan Michael. Dalam penelitian ini menggunakan tingkat kesalahan atau taraf signifikan 5\% (0,05). Maka dari populasi 118 guru dapat diambil sampel sejumlah 88 guru.

Dalam penelitian ini terdapat dua variabel yaitu: satu variabel bebas $(\mathrm{X})$ dan satu variabel terikat $(\mathrm{Y})$. Penelitian ini bertujuan untuk menemukan dan mengukur besarnya pengaruh variabel bebas "Metode bercerita" $(\mathrm{X})$ terhadap variabel terikat "Kecerdasan linguistik anak usia dini” (Y). Hubungan antara kedua variabel dapat digambarkan sebagai berikut:

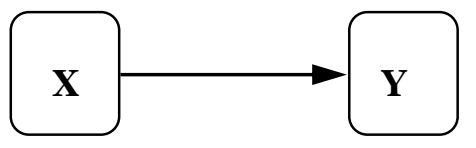

$$
\begin{aligned}
& \mathrm{X}=\text { Metode bercerita } \\
& \mathrm{Y}=\text { Kecerdasan linguistik anak usia dini }
\end{aligned}
$$

Gambar 1. Paradigma Sederhana

Tabel 1. Kisi-kisi Angket Variabel X (Metode Bercerita)

\begin{tabular}{|l|l|l|l|c|}
\hline Variabel & \multicolumn{1}{|c|}{ Indikator } & \multicolumn{1}{|c|}{ Deskriptif } & \multicolumn{1}{|c|}{ No. Item } & $\begin{array}{c}\text { Jumlah } \\
\text { Item }\end{array}$ \\
\hline Metode & a. Strategi bercerita & Pengertian & $1,2,3,4$ & 4 \\
Bercerita & b. Teknik bercerita & Tugas guru & & \\
(X) & & Pengertian & $5,6,7,8$ & 4 \\
& c. Bentuk-bentuk & Kompetensi guru & $9,10,11,12,13$, & 7 \\
\hline
\end{tabular}

Tabel 2. Kisi-kisi Angket Variabel Y (Kecerdasan Linguistik)

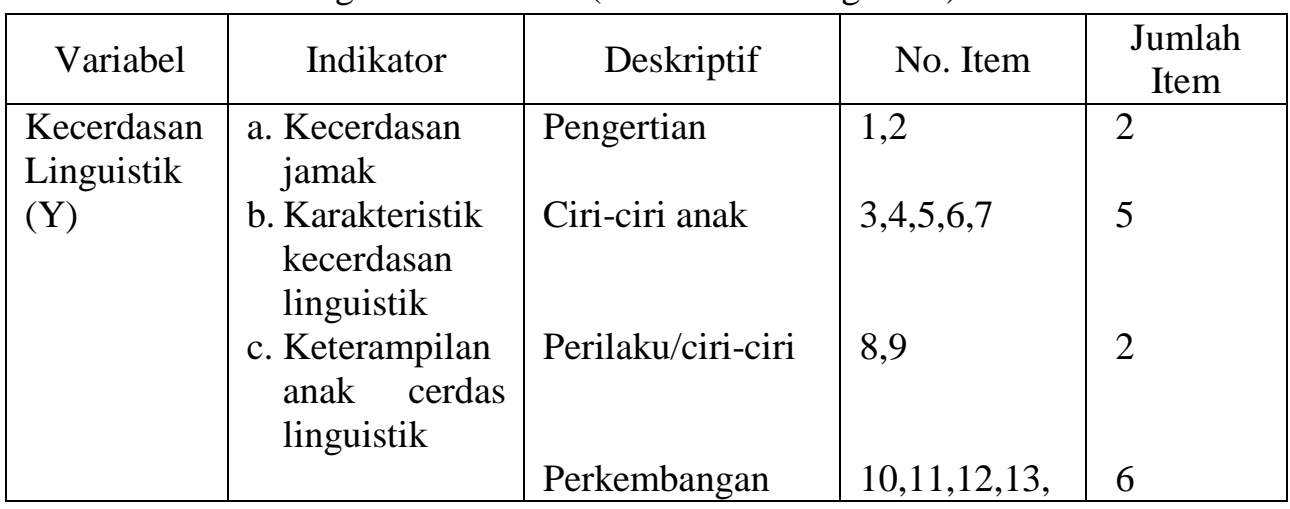




\begin{tabular}{|l|l|l|l|l|}
\hline & $\begin{array}{l}\text { d. Keberbakatan/ } \\
\text { minat anak } \\
\text { cerdas } \\
\text { linguistik }\end{array}$ & 14,15 & \\
\hline
\end{tabular}

\section{Hipotesis}

Hipotesis adalah dugaan yang mungkin benar, atau mungkin salah. Hipotesis akan ditolak jika salah atau palsu, dan akan diterima jika fakta-fakta membenarkannya. (Sutrisno Hadi, 2001). Atau dapat juga diartikan sebagai jawaban sementara terhadap masalah penelitian yang kebenarannya masih terus diuji secara empiris.

Ho = Tidak ada hubungan atau pengaruh metode bercerita terhadap kecerdasan linguistik anak usia dini di TK se-Kecamatan Parakan.

$H a=$ Ada hubungan atau pengaruh metode bercerita terhadap kecerdasan linguistik anak usia dini di TK se-Kecamatan Parakan.

Bedasarkan kerangka pikir di atas maka penulis mengajukan hipotesis bahwa ada hubungan antara metode bercerita terhadap kecerdasan linguistik anak usia dini di TK se-Kecamatan Parakan.

\section{Uji Validitas Instrumen}

Untuk menguji validitas data digunakan rumus regresi linier. Hasil dari uji instrumen penelitian pertama untuk 30 responden dengan 20 butir pertanyaan belum valid. Kemudian dilakukan uji instrumen penelitian kedua untuk 30 responden dengan 15 pertanyaan variabel X yaitu metode bercerita $100 \%$ valid, dan variabel Y yaitu kecerdasan linguistik anak usia dini $100 \%$ valid. Jadi dapat disimpulkan bahwa instrumen ini telah memenuhi standar validitas dan tingkat kepercayaan sehingga dapat dilanjutkan.

\section{HASIL PENELITIAN}

\section{Uji Validitas dan Reliabilitas}

Hasil dalam penelitian ini data dapat dipercaya apabila $r_{\text {hitung }}$ reliabilitas instrumen $>$ dari $r_{\text {tabel. }}$. Untuk ukuran standar dalam penelitian tingkat signifikan menggunakan a: 5\% signifikan 5: 0,05. Dalam $r$ tabel bila jumlah sampel $\mathrm{N}$ : 88 dan signifikan 0,05 diperoleh $r$ tabel: 0,208 . Sedangkan dalam data yang disajikan oleh SPSS didapat $r_{\text {hitung }}>r_{\text {tabel. }}$.

Jadi data tersebut adalah dapat dipercaya kevalidan data tercantum dalam lampiran di variabel $\mathrm{X}$ reliabel dan variabel Y reliabel yang nilainya: 100\% karena masing-masing responden $r_{\text {hitung }}$ selalu terbesar dari $r$ tabel.

Untuk variabel X valid bila N: 88 validitas $100 \%$ diperoleh valid statistiknya $86,2 \%$. Sedangkan untuk variabel Y didapat reliabel statistiknya 87,5\%.

\section{Analisis Deskriptif}

Hasil analisis tabel Descriptive Statistics pengaruh metode bercerita terhadap kecerdasan linguistik anak usia dini yaitu untuk variabel $\mathrm{X}$ (metode bercerita) didapat mean sebesar 49,98 dan standar deviasi 5,47 sedangkan untuk variabel Y (kecerdasan linguistik anak usia dini) didapat mean 48,39 dan standar deviasi 5,22 .

\section{Korelasi Product Moment}

Berdasarkan hasil analisis yang ditampilakan Tabel Model Summary ${ }^{b}$ diketahui bahwa korelasi parsial antara metode bercerita dan kecerdasan linguistik anak usia dini dengan korelasi product moment by Pearson. Hasil korelasi parsial didapat nilai $\mathrm{r}$ hitung sebesar 0, 475. 
Nilai korelasi ini tergolong cukup kuat karena mendekati 0,600 dan memiliki nilai positif sehingga dapat dikatakan pola hubungan antara metode bercerita dan kecerdasan linguistik anak usia dini adalah searah. Artinya, semakin tinggi kemampuan metode bercerita guru akan semakin tinggi pula tingkat kecerdasan linguistik anak usia dini. Begitu pula sebaliknya, semakin rendah kemampuan metode bercerita guru maka semakin rendah pula tingkat kecerdasan linguistik anak usia dini.

Koefisien determinasi (KD) menunjukkan nilai sebesar 0,225 atau sebesar 22,5\% dari hasil ( $\left.\mathrm{r}^{2} \mathrm{x} 100 \%\right)$. Artinya variabel kecerdasan linguistik anak usia dini dipengaruhi oleh metode bercerita sebesar 22,5\% dan sisanya 77,5\% dipengaruhi faktor lain selain metode bercerita, antara lain: faktor psikologis, faktor keluarga, faktor masyarakat dan lingkungan.

\section{Regresi Linier Sederhana}

Mengacu pada tabel Coefficients ${ }^{\mathrm{a}}$ diperoleh persamaan: $\mathrm{Y}=25,720+0,453 \mathrm{X}$. Konstanta sebesar 25,720 menyatakan bahwa jika variabel kecerdasan linguistik bernilai nol, maka metode bercerita adalah sebesar 25,720 satuan.

Berdasarkan hasil uji terlihat bahwa grafik histogram memperlihatkan sebaran data menyebar ke seluruh daerah kurva normal, sehingga dapat dinyatakan bahwa data berdistribusi normal. Sementara hasil uji menggunakan P-P Plot menunjukkan bahwa data mengikuti garis diagonal sehingga dinyatakan bahwa data berdistribusi normal.

\section{Uji Hipotesis}

Dari hasil perhitungan didapat kesimpulan bahwa metode bercerita (X) memiliki hubungan yang signifikan dengan kecerdasan linguistik anak usia dini (Y). Hasil uji t dalam tabel Coefficients ${ }^{\mathrm{a}}$ diperoleh nilai $\mathrm{t}_{\text {hitung }}$ sebesar 5,639.

Sedangkan statistik tabel $\mathrm{t}\left(\mathrm{t}_{\text {tabel }}\right)$ diperoleh $\mathrm{t}_{\text {tabel }}$ sebesar 1,658 artinya $\mathrm{t}_{\text {hitung }}>\mathrm{t}$ tabel $(5,639>1,658)$. Sehingga dapat ditarik kesimpulan bahwa variabel bebas metode bercerita $(\mathrm{X})$ secara parsial memiliki hubungan positif dan signifikan terhadap variabel terikat kecerdasan linguistik anak usia dini (Y). hasil uji t ini sejalan dengan sig 0,000 yang jauh lebih kecil dari alpha 0,05 sehingga disimpulkan bahwa variabel X memiliki pengaruh signifikan terhadap variabel Y. Maka hipotesis alternatif (Ha) diterima sedangkan hipotesis nol (Ho) ditolak.

\section{DISKUSI}

Metode bercerita merupakan suatu cara yang dilakukan oleh guru untuk menyampaikan pesan atau materi pelajaran yang disesuaikan dengan kondisi anak didik. Sedangkan kecerdasan linguistik merupakan kemampuan menggunakan bahasa untuk menyatakan gagasan tentang dirinya dan memahami orang lain serta untuk mempelajari kata-kata baru atau bahasa lain.

Penelitian ini untuk mengetahui sejauh mana pengaruh metode bercerita sebagai variabel bebas terhadap kecerdasan linguistik sebagai variabel terikat. Berdasarkan kajian teori bahwa penggunaan metode bercerita yang tepat dapat meningkatkan kecerdasan linguistik anak. Anak-anak yang cerdas dalam bahasa menyukai kegiatan bermain yang memfasilitasi kebutuhan mereka untuk berbicara, bernegosiasi dan juga mengekspresikan perasaan dan pikiran dalam bentuk kata-kata. Mereka cenderung suka bercerita, membaca, menulis, bermain kata, menghafal kata-kata dan berbagai permainan yang berhubungan dengan kosakata/bahasa.

Anak lahir ke dunia ini pada dasarnya sudah membawa bakat dan kecerdasan masing-masing yang berbeda-beda. Walaupun demikian, pemilihan metode pembelajaran yang digunakan guru juga mempengaruhi perkembangan kecerdasan anak didik mereka. Cerita adalah suatu kegiatan yang dilakukan oleh guru kepada murid-muridnya, ayah kepada anak-anaknya, guru bercerita kepada 
pendengarnya. Bercerita juga dapat menjadi media untuk menyampaikan nilai-nilai yang berlaku di masyarakat/kehidupan sehari-hari.

Metode bercerita merupakan salah satu metode yang banyak digunakan di Taman Kanak-kanak dengan membawakan cerita kepada anak secara lisan. Dalam penyampaiannya guru harus menarik dan mengundang perhatian anak serta tidak lepas dari tujuan pendidikan sehingga anak dapat memahami isi cerita itu.

Dari hasil penelitian pengaruh metode bercerita terhadap kecerdasan linguistik anak usia dini di TK seKecamatan Parakan mempunyai pengaruh yang signifikan sebesar 22,5\% dan sebaliknya 77,5\% berasal dari faktor lain seperti psikologis, faktor keluarga, lingkungan sekolah dan masyarakat.

\section{KESIMPULAN}

Hasil penelitian yang dapat diambil adalah sebagain berikut: (1) Penggunaan metode bercerita di TK se-Kecamatan Parakan yang ditetapkan melalui hasil angket didapat nilai tertinggi adalah 4 dan nilai adalah terendah 2,53 sedangkan rata-rata angket adalah 3,45. Artinya, penggunaan metode di TK seKecamatan Parakan sering digunakan karena berdasarkan rata-rata angket yang mendekati nilai 4. (2) Kecerdasan linguistik anak usia dini di TK se-Kecamatan Parakan berdasarkan hasil angket didapat nilai tertinggi adalah 3,93 dan nilai terendah adalah 2,46 sedangkan nilai rata-rata angket adalah 3,26. Artinya, tingkat kecerdasan linguistik anak usia dini di TK se-Kecamatan Parakan baik dilihat dari ratarata angket yang mendekati nilai 4. (3) Ada pengaruh $22,5 \%$ antara metode bercerita terhadap kecerdasan linguistik anak usia dini di TK se-Kecamatan Parakan. Sedangkan 74,5\% dipengaruhi dari faktor lain, antara lain: faktor keluarga, masyarakat, dan lingkungan sekolah maupun rumah. Maka hipotesis alternatif (Ha) diterima sedangkan hipotesis nol (Ho) ditolak.

\section{REFERENSI}

Sugiyono, Metode Penelitian Kuantitatif Kualitatif dan R\&D, Bandung; Alfabeta,2009.

Sutrisno, Hadi, Metodologi Research, Yogyakarta: Andi, 2001.

Arikunto, Suharsini, Prosedur Penelitian, Rineka Cipta; Jakarta,2002. , Prosedur Penelitian Suatu Pendekatan Praktik, Rineka Cipta; Yogyakarta,1991.

Nasution, MA, Metode Research: Penelitian Ilmiah, Bumi Aksara; Jakarta,2006

R., Moeslichatoen, Metode Pengajaran Di Taman Kanak-kanak, Jakarta; Rineka Cipta, 2004.

Winda Gunarti, dan Hapinudin, Pedoman Perencanaan dan Evaluasi Pengajaran Di Taman Kanakkanan, Jakarta; PGTK Darul Qolam,1996.

Departemen Pendidikan dan Kebudayaan, Program Kegiatan Belajar Taman Kanak-kanak, Jakarta, 1996.

Departemen Pendidikan dan Kebudayaan, Metode Khusus Pengembangan Kemampuan Berbahasa, Jakarta,1996.

Surya, Sutan, Melejitkan Multiple Intelligence Anak Sejak Dini, Andi,2004

Kaufeldt, Martha, Wahai Para Guru Ubahlah Cara Mengajarmu!, Jakarta: PT Indeks,2008.

Djiwandono, Sri Esti Wuryani, Konseling dan Terapi dengan Anak dan Orang tua, Jakarta; PT Gramedia Widiasarana Indonesia,2005.

Seefeldt, Carol \& Wasik, Barbara A., Pendidikan Anak Usia Dini (Menyiapkan Anak Usia Tiga, Empat, dan Lima Tahun Masuk Sekolah), Jakarta ; PT Indeks, 2008. 
Yus, Anita, Model Pendidikan Anak Usia Dini, Jakarta; Kencana, 2011.

Sujiono, Yuliani Nurani, Konsep Dasar Pendidikan Anak Usia Dini, Jakarta; PT Indeks, 2011.

Asnelli Ilyas. Mendambakan Anak Soleh. Bandung: Al-Bayan, 1997.

Muslihudin\&Agustina, M. Mengenal dan Mengembangkan Potensi Kecerdasan Jamak Anak Usia TK dan RA. Bandung: Rizqi Press, 2008.

Rustina, N. Peningkatan Kemampuan Menyimak Cerita Pada Anak Usia 4-5 Tahun Melalui Aktivitas Mendongeng (Penelitian Tindakan Tentang Keterampilan Menyimak Cerita Pada Anak Di Smart Kids Pre-School Margahayu Raya Bandung), Skripsi. Bandung: UPI, 2007.

Musfiroh, T. Bercerita Untuk Anak Usia Dini, Jakarta: Depdiknas, 2005. 